\title{
Contribution of advection to the carbon budget measured by eddy covariance at a steep mountain slope forest in Switzerland
}

\author{
S. Etzold, N. Buchmann, and W. Eugster \\ ETH Zurich, Institute of Plant, Animal and Agroecosystem Sciences, Switzerland \\ Received: 17 February 2010 - Published in Biogeosciences Discuss.: 3 March 2010 \\ Revised: 22 June 2010 - Accepted: 12 July 2010 - Published: 17 August 2010
}

\begin{abstract}
We calculated the contribution of advection to the $\mathrm{C}$ budget measured by the eddy covariance (EC) technique for a steep and forested mountain site (CarboEurope site CHLae, Lägeren, Switzerland) during the growing season 2007 (May to August). Thereby we followed two approaches: (1) the physical correction of the EC data for directly measured advection terms and (2) the $u_{*}$ filter approach that replaces periods with $u_{*}$ below a site-specific threshold with empirically modelled fluxes. We found good agreement between the two approaches in terms of daily (linear regression slope: $0.78 \pm 0.04$, intercept: $0.68 \pm 0.29 \mu \mathrm{mol} \mathrm{m}^{-2} \mathrm{~s}^{-1}$, adj. $R^{2}=$ 0.78 ) and seasonal sums of gross fluxes (difference $\leq 12 \%$ ), when using a $u_{*}$ threshold of $0.3 \mathrm{~m} \mathrm{~s}^{-1}$ and correcting EC for horizontal advection only. Incorporating also vertical advection into the mass balance equation resulted in unrealistic and highly erratic fluxes. However, on a daily basis vertical advection cancelled out to nearly zero. The $u_{*}$ filter seems to account primarily for respiration fluxes, which are mainly affected by horizontal advection. We could confirm our corrections by a cross-validation with independent approaches, such as soil respiration chamber measurements, light curves and energy budget closure. Our results show that flux measurements on steep sites with complex topography are possible. Actually, sloping sites seem to have the advantage over flat sites that advection measurements can be reduced to a simplified two-dimensional measurement approach due to the two-dimensional characteristics of the wind field at those sites.
\end{abstract}

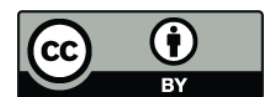

Correspondence to: S. Etzold (sophia.etzold@ipw.agrl.ethz.ch)

\section{Introduction}

The eddy covariance (EC) method has become an important tool to study long-term gas exchange processes between the atmosphere and the biosphere, since it is the only method that allows direct measurements of gas exchange at the ecosystem level. However, several requirements have to be fulfilled to obtain reliable and spatially representative estimates of the $\mathrm{CO}_{2}$ exchange rates. According to Baldocchi (2003), EC measurements are most accurate when atmospheric conditions are steady, underlying vegetation is homogeneous, and instruments are set up over flat terrain of sufficiently spatial extension. Under stable conditions, largest uncertainties and errors in EC measurements are introduced by intermittent turbulence and advection. On sloping terrain, the occurrence of advection is assumed to be the largest problem (Aubinet, 2008). Additionally, as homogeneity tends to decrease with increasing roughness length, forests create more difficult preconditions for EC measurements than short-statured vegetation types. Thus, forests on sloping terrain are regarded as most difficult sites for flux measurements (Baldocchi et al., 2000). Due to these non-ideal conditions, EC studies in mountainous ecosystems are rare. However, mountains cover $25 \%$ of the world's area (UNEP, 2008) and mountainous ecosystems are supposed to be heavily affected by anthropogenic and climatic impacts (Huber et al., 2005; FAO, 2008; Metzger et al., 2008). Furthermore, forest ecosystems act as an important sink within the global carbon cycle (e.g., Janssens et al., 2003; Luyssaert et al., 2008). Thus, regions with complex topography are among the most important regions for determining local and global carbon and water budgets (Schimel et al., 2002). Therefore it is necessary to extend the application of the EC technique to mountain ecosystems, such as mountain forests to understand ongoing processes and be able to include these ecosystems into global calculations and models.

Published by Copernicus Publications on behalf of the European Geosciences Union. 
Contrary to the persistent hypothesis that EC measurements are most precise on flat and homogeneous terrain, large advection fluxes were observed also on very flat areas (Feigenwinter et al., 2008). Due to their openness and lack of orography, wind is not channeled over such areas and shows no systematic pattern like wind systems in mountainous areas. This makes the measurement of advective fluxes on flat areas extremely challenging and requires substantial technical and thus financial efforts. In contrast, wind patterns in mountains are dominated by local wind systems, such as diurnal slope or valley winds (Whiteman, 2000), leading to a two-dimensional wind pattern, which makes the assessment of advective fluxes much easier. However, deviations from this general rule are found during synopticscale weather events. Often, these events are associated with adverse weather conditions (e.g., rain, snowfall), where EC measurements become more uncertain or even fail, irrespective of locality or topographical conditions. This is also the case at our study site. Being a mixed forest located on a relatively steep slope of the Jura mountain range and featuring a highly complex small-scale topography, this site poses apparently challenging preconditions for applying the EC technique. But just because of this steep slope and the pronounced ridge, winds above the canopy and inside the canopy are strongly channeled, which offers the possibility to assess advection in a simplified two-dimensional approach.

Integration of the advection term directly into the $\mathrm{CO}_{2}$ mass balance for calculation of net ecosystem exchange (NEE) is still an important topic in the current scientific discussion. Measured advection fluxes presently show large scatter and errors that are in the same order of magnitude as measured exchange fluxes (Heinesch et al., 2007). Usage of hourly advection values is therefore regarded as difficult (Feigenwinter et al., 2008) and physical correction allows not always an improvement of night-time fluxes (Aubinet, 2008). Correction of EC measurements is usually done by excluding periods with stable stratification and subsequent data gap-filling based on validation periods with turbulent conditions (Moffat et al., 2007). Generally, the friction velocity $u_{*}$ is used as a filter criterion, as below a certain empirical $u_{*}$ threshold insufficient stationarity and high temporal variability of turbulence as well as the occurrence of advection are assumed (Aubinet et al., 2003; Gu et al., 2005). However, the weakness of this approach was addressed in several studies (Moureaux et al., 2006; Papale et al., 2006; Ruppert et al., 2006; Kutsch et al., 2009) and alternative correction methods have been developed (Staebler and Fitzjarrald, 2004; Van Gorsel et al., 2008; Acevedo et al., 2009). Nevertheless, Aubinet (2008) recently recommended rather to filter EC measurements by a $u_{*}$ threshold than to correct them physically for advection. However, the contribution of advection to measured turbulent fluxes is essential when we strive to get reliable estimates of the gross fluxes of ecosystems, i.e., gross primary production (GPP) and ecosystem respiration (Reco), as used in global models and estimates of

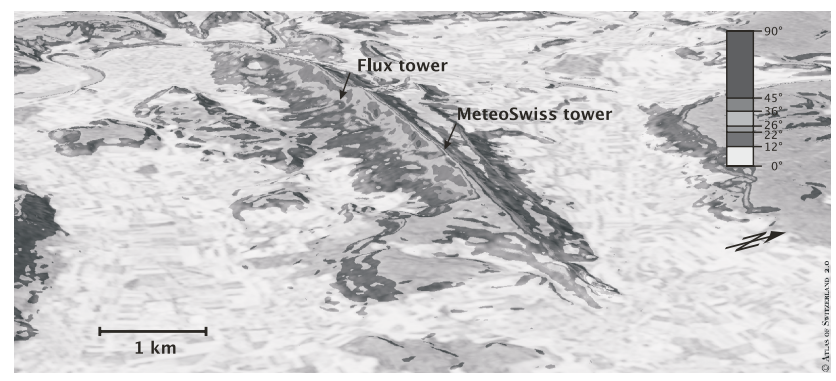

Fig. 1. The Lägeren mountain ridge. Colours indicate the slope angle of the respective area. The Lägeren flux tower and the MeteoSwiss tower are marked. (Reproduced with authorisation of swisstopo (JA082267)).

source and sink strength of ecosystems. In our study we calculated the contribution of advection to the $\mathrm{C}$ budget, with special reference to the respiration flux, since this flux is known to be generally underestimated by the EC method on longer time scales (Goulden et al., 1996). Hence, we focus in this paper on daily and monthly fluxes during the vegetation period. The objectives of our study were (1) to quantify advection with a relatively simple and cost efficient approach, (2) to calculate the contribution of advection to the gross ecosystem fluxes by applying two approaches for calculation: the $u_{*}$ filter approach and the physical correction by direct advection measurements, and (3) to validate our correction approaches with independently derived data.

\section{Methods}

\subsection{Study site and instrumentation}

The Lägeren research site $\left(47^{\circ} 28^{\prime} 42^{\prime \prime} \mathrm{N}, 8^{\circ} 21^{\prime} 52^{\prime \prime} \mathrm{E}\right.$, $682 \mathrm{~m}$ a.s.l. (base of flux tower) is located on the relatively steep (in average $24^{\circ}$, maximum $45^{\circ}$ ), south-facing slope of the Lägeren mountain, north-west of Zurich, Switzerland. The Lägeren mountain is the easternmost outcrop of the Jura mountain range of about $11 \mathrm{~km}$ length and $1.5 \mathrm{~km}$ width. The site is part of the Swiss air quality monitoring network (NABEL) since 1986 (NABEL, 2010). Routine $\mathrm{CO}_{2}$ and $\mathrm{H}_{2} \mathrm{O}$ flux measurements by the eddy covariance (EC) method are running since 2004 as a contribution to the Integrated Project CarboEurope-IP and FLUXNET network (Eugster et al., 2007).

The linear topography of the Lägeren mountain (Fig. 1) leads to a strongly channeled atmospheric flow above the canopy along the ridge with two distinct lobes of the flux footprint towards the West (most frequent wind direction above the canopy is $\left.240-260^{\circ}\right)$ and the East. Vegetation cover is a productive mixed forest dominated by beech $(\mathrm{Fa}$ gus sylvatica), with a high diversity concerning tree species, age and diameter distributions. Mean leaf area index (LAI) during the vegetation period ranges from 1.7 to $5.5 \mathrm{~m}^{2} \mathrm{~m}^{-2}$. 
Mean tree height is $30.6 \mathrm{~m}$, and the aerodynamic displacement height was estimated at $18 \mathrm{~m}$ (Eugster et al., 2007). The surrounding of the Lägeren is dominated by agricultural land-use. The nearest small industrial towns Baden and Wettingen are located $3 \mathrm{~km}$ west of the flux tower. Mean annual temperature is $8.6^{\circ} \mathrm{C}\left(2007: 9.1^{\circ} \mathrm{C}\right)$ and mean annual precipitation is $950 \mathrm{~mm}$ (2007: $914 \mathrm{~mm}$ ) (Swiss air quality monitoring network NABEL, 2010). Fog has a great importance on the local climate.

The flux tower is located in direct vicinity to a small forest gap that originates from the heavy winter storm Lothar in 1999. EC instrumentation, consisting of a triaxial sonic anemometer (Gill Solent HS, Gill Instruments Ltd., Lymington, UK) and an open-path non-dispersive infrared gas analyzer (IRGA) model 7500 (Licor, Lincoln, Nebraska, USA), is mounted at a height of $47 \mathrm{~m}$ above ground, $15 \mathrm{~m}$ above the mean tree height. The upper platform of the tower is also equipped with instruments for measuring standard meteorological variables, such as radiation components (Kipp \& Zonen CNR1, Delft, Netherlands), air temperature and relative humidity (Rotronic MP101A temperature and relative humidity probe, Bassersdorf, Switzerland). In vicinity of the flux tower, we measure soil temperature and moisture in $5 \mathrm{~cm}$ soil depth (Decagon $\mathrm{ECH}_{2} \mathrm{O}$ EC-20 probes, Pullman, WA, USA). Mean soil heat flux is calculated from two soil heat flux plates (Hukseflux heat flux plate HFP01, Delft, Netherlands) installed side by side at $3 \mathrm{~cm}$ soil depth. Soil heat flux is corrected for the change of heat storage of the soil layer above the heat flux plates according to Montheith and Unsworth (1990). Measurements are controlled and stored by a data logger (CR10X, Campbell Scientific Inc., Loughborough, UK).

\subsection{Theoretical considerations}

The full three-dimensional advection-diffusion equation for $\mathrm{CO}_{2}$ concentration $\bar{c}$ is

$$
\begin{aligned}
\frac{\partial \bar{c}}{\partial t}=F_{c} & -\left(\frac{\partial}{\partial x} \overline{u c}+\frac{\partial}{\partial y} \overline{v c}+\frac{\partial}{\partial z} \overline{\omega c}\right) \\
& -\left(\frac{\partial}{\partial x} \overline{u^{\prime} c^{\prime}}+\frac{\partial}{\partial y} \overline{v^{\prime} c^{\prime}}+\frac{\partial}{\partial z} \overline{\omega^{\prime} c^{\prime}}\right) .
\end{aligned}
$$

In the simplification made here we only look at a twodimensional cross-section along the mean wind $\bar{u}$ near the forest floor surface, which makes $\bar{v}=0$, and we neglect the turbulent flux divergence in the two dimensions ( $\mathrm{x}$ and $\mathrm{y}$ ) parallel to the ground surface. This reduces Eq. (1) to

$$
\frac{\partial \bar{c}}{\partial t}=F_{c}-\frac{\partial}{\partial x} \overline{u c}-\frac{\partial}{\partial z} \overline{\omega c}-\frac{\partial}{\partial z} \overline{\omega^{\prime} c^{\prime}},
$$

which now consists of the storage term, the true $\mathrm{CO}_{2}$ flux $F_{C}$, the advection terms in along-slope (x direction) and slopenormal (y) direction, and the turbulent flux divergence approximated by the above-canopy eddy covariance flux measurements $\left(\overline{\omega^{\prime} c^{\prime}}\right)$ at height $z_{\mathrm{EC}}$ and the knowledge that there is no turbulent flux at the physical ground surface, $\overline{\omega^{\prime} c^{\prime}}(0)$. In principle, with a co-ordinate rotation that forces $\overline{\omega^{\prime}}=0$ the vertical advection term could also be neglected if this assumption would be valid at all heights. We however kept the vertical advection term in our equation set. Eq. (2) was integrated layer-wise, from the forest floor, up to the EC height $z_{\mathrm{EC}}$.

Although a three-dimensional approach to quantify advection would be ideal, our two-dimensional approach is still a physical approximation to true conditions. However, a few additional assumptions have to be made: (1) the $\mathrm{CO}_{2}$ concentration field in the layer where advection occurs has a simple gradient without curvature; (2) the gradient is along the slope direction given by the katabatic drainage flow winds or the anabatic upslope winds. With this simplification we expect to get good approximations of the advective components in $F_{C}$ as long as the $\mathrm{CO}_{2}$ concentration field is a first-order linear trend surface with its main gradient along the prevailing nearsurface wind directions (see Fig. 1 in Final Response). Under circumstances where these assumptions are a good approximation to the real conditions - as we expect at the Lägeren field site - even a wind direction shift by $90^{\circ}$ from the forest surface to the EC measurement height would be unproblematic. In fact, in cases where the mean wind component at EC height is perpendicular to the main $\mathrm{CO}_{2}$ gradient in Fig. 1 in Final Response, the $\partial \bar{c} / \partial x$ component in Eq. (2) would be zero and the EC flux measurement should even be closer to the true flux $F_{C}$. Hence, our simplified Eq. (2) might even overestimate advective fluxes if wind directions vary across the canopy.

Horizontal advection $\left(\mathrm{F}_{\mathrm{HA}}\right)$ is here defined as the advection flux surface-parallel along the slope due to drainage flow. Drainage horizontal advection for a layer depth of $2 \mathrm{~m}$ $\left(\mathrm{F}_{\mathrm{HA} 2 \mathrm{~m}}\right)$ was calculated according to Eq. (3):

$$
F_{\mathrm{HA} 2 \mathrm{~m}}=\int_{0}^{2} \overline{u_{c}}(z) \frac{\partial \bar{c}}{\partial x} d z
$$

with $u_{c}=$ wind component along the $\mathrm{CO}_{2}$ gradient measurement $\left(\mathrm{m} \mathrm{s}^{-1}\right), z=$ integration height $(\mathrm{m})$, and $\frac{\partial \bar{c}}{\partial x}=$ horizontal gradient of the $\mathrm{CO}_{2}$ mixing ratio $\left(\mathrm{ppm} \mathrm{m}^{-1}\right.$ ) (Feigenwinter et al., 2004), derived from the horizontal $\mathrm{CO}_{2}$ concentration profile described in Sect. 2.3.

Vertical advection $\left(F_{\mathrm{VA}}\right)$ is calculated according to Eq. (4):

$$
F_{\mathrm{VA}}=\int_{0}^{z_{\mathrm{EC}}} \bar{w}(z) \frac{\partial \bar{c}}{\partial z} d z,
$$

with $w=$ vertical wind speed $\left(\mathrm{m} \mathrm{s}^{-1}\right), \frac{\partial \bar{c}}{\partial z}=$ vertical gradient of the $\mathrm{CO}_{2}$ mixing ratio (ppm m${ }^{-1}$ ) (Feigenwinter et al., 2004). According to Lee's (1998) notation for the vertical advection, Eq. (4) results in:

$$
F_{\mathrm{VA}}=\bar{w}\left(z_{\mathrm{EC}}\right)\left[\bar{c}\left(z_{\mathrm{EC}}\right)-\langle c\rangle\right],
$$




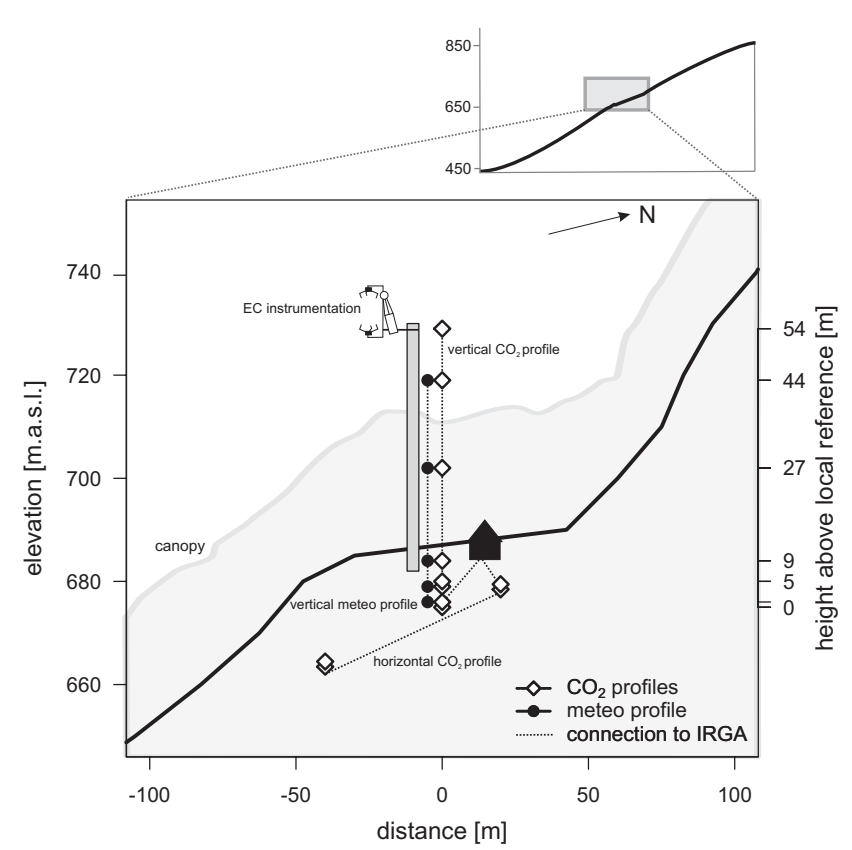

Fig. 2. Experimental set-up of EC flux and advection measurements. $675 \mathrm{~m}$ a.s.l. is used as local reference zero height. Note that the $\mathrm{x}$ - and $\mathrm{y}$-axis have different scales. For details see text.

whereby

$\langle c\rangle=\frac{1}{z_{E C}} \int_{0}^{z_{\mathrm{EC}}} \bar{c}(z) d z$,

The vertical $\mathrm{CO}_{2}$ concentration gradient is averaged across the eight measurement heights of the vertical $\mathrm{CO}_{2}$ profile described in Sect. 2.3. The mean vertical component of wind velocity is derived from the high frequency measurements of the 3-D sonic anemometer of the EC instrumentation on top of the tower. Tilt correction of the mean vertical velocity component was done according to Feigenwinter et al. (2004):

$$
\begin{aligned}
& \bar{w}\left(z_{\mathrm{EC}}\right)=\bar{w}\left(z_{\mathrm{EC}}\right)_{\text {measured }} \\
& -\sqrt{\bar{u}^{2}\left(z_{\mathrm{EC}}\right)+\bar{v}^{2}\left(z_{\mathrm{EC}}\right)} \tan \left[a_{0}+a_{1} \sin \left(\alpha+a_{2}\right)\right] .
\end{aligned}
$$

With $u$ and $v=$ measured wind components in $\mathrm{x}$ and $\mathrm{y}$ direction, $\alpha=$ wind direction in degree. The coefficients $a_{0}, a_{1}$ and $a_{2}$ coefficients were determined by a sinusoidal fit of the tilt angle against wind direction using the whole data set of the year 2007, resulting in $a_{0}=2.293^{\circ}$ (offset), $a_{1}=21.226^{\circ}$ (amplitude) and $a_{2}=272.705^{\circ}$ (phase shift).

\section{3 $\mathrm{CO}_{2}$ concentration profiles}

We installed a vertical $\mathrm{CO}_{2}$ concentration profile at eight heights: $0.1 \mathrm{~m}, 1 \mathrm{~m}, 3 \mathrm{~m}, 5 \mathrm{~m}, 9 \mathrm{~m}, 27 \mathrm{~m}, 44 \mathrm{~m}$, and $54 \mathrm{~m}$ above ground (Fig. 2). The lowest point $(0.1 \mathrm{~m})$ represents the local topographical minimum of the footprint area. The

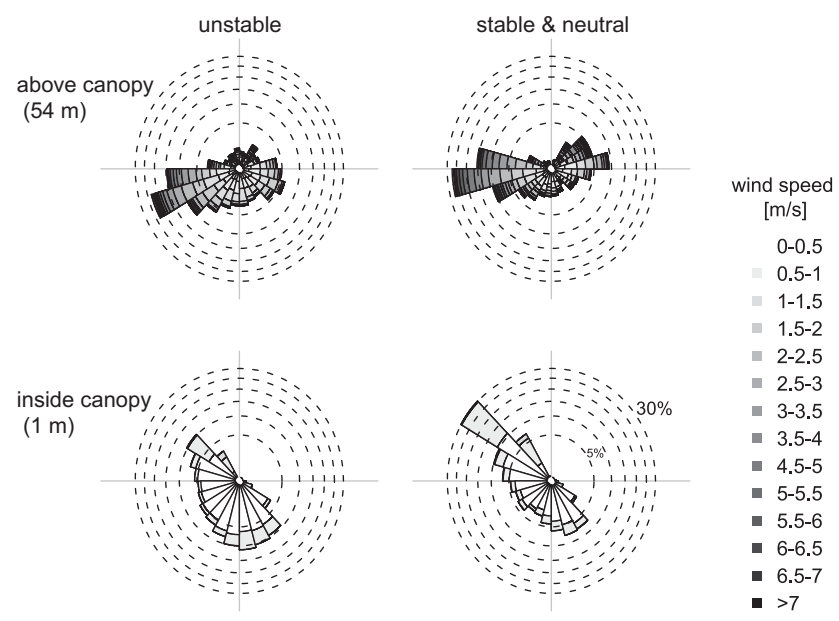

Fig. 3. Wind roses for above $(54 \mathrm{~m})$ and inside the canopy (1m) for two stability classes (stable \& neutral: $z / L>=0$, unstable: $z / L<0)$. Each broken circle refers to $5 \%$ frequency classes in the respective wind direction sector. Data were measured during May to August 2007.

measurement points at 9 to $54 \mathrm{~m}$ height are located along the flux tower, thus the measurement point at $54 \mathrm{~m}$ corresponds to the EC measurement height.

The horizontal (along-surface) $\mathrm{CO}_{2}$ profile in vicinity to the flux tower (minimum distance $20 \mathrm{~m}$ ) was installed at two heights $(0.1 \mathrm{~m}, 1 \mathrm{~m})$ with a distance of $60 \mathrm{~m}$ (Fig. 2). The horizontal profile is oriented along the prevailing wind direction at $1 \mathrm{~m}$ height $\left(315^{\circ}\right.$; Fig. 3$)$.

$\mathrm{CO}_{2}$ intake hoses were connected to a home-built valve switching unit with continuously purged air inlets, consisting of an inner ethylene copolymer coating, an aluminium layer, and an outer high-density polyethylene jacket (Synflex $^{\mathrm{TM}}$ Type 1300, I.D.:4 mm, Johannsen AG, Zurich, Switzerland). Airflow was directed through a small pump inside the valve switching unit to an IRGA (Licor Li-7000, Lincoln, Nebraska, USA). Thus, all twelve points of the vertical and horizontal profiles were measured by the same IRGA. The flow through the selection unit during measurements was kept at $11 \mathrm{~min}^{-1}$ and at $0.41 \mathrm{~min}^{-1}$ during purging. Switching of the air selection unit and storing of the IRGA analog output $\left(\mathrm{CO}_{2}\right.$ concentration, $\mathrm{H}_{2} \mathrm{O}$ concentration, cell pressure and temperature) was controlled by a data logger (CR10, Campbell Scientific Inc., Loughborough, UK). Each inlet was consecutively selected for $30 \mathrm{~s}$, whereby the $\mathrm{CO}_{2}$ concentration reading was done during the last ten seconds to avoid contamination by the previous measurement. One measurement cycle for all twelve sampling channels was set to $10 \mathrm{~min}$ (twelve channels à $30 \mathrm{~s}=6 \mathrm{~min}$, with a four minute break to yield equal sampling repetitions). Three single measurements were aggregated to $30 \mathrm{~min}$ averages then. The reference flow path of the IRGA was constantly scrubbed with a soda lime and desiccant $\left(\mathrm{Mg}\left(\mathrm{ClO}_{4}\right)_{2}\right)$ that was changed 
every few weeks when chemicals were exhausted. Every day a reference gas with a known $\mathrm{CO}_{2}$ concentration was purged through the manifold. According to the drift of the daily reference gas measurements, $\mathrm{CO}_{2}$ concentration values were corrected. Calibration of zero offset and span correction of the IRGA was done manually every few weeks.

\subsection{Vertical meteorological profile}

Corresponding to the $\mathrm{CO}_{2}$ profile, vertical profiles of air temperature and relative air humidity (Fischer T/F-Sensors, type 431418, K. Fischer GmbH, Drebach, Germany), wind speed and direction (Gill 2-D sonic anemometers, Gill Instruments Ltd., Lymington, UK) were measured at five heights $(1 \mathrm{~m}$, $5 \mathrm{~m}, 9 \mathrm{~m}, 27 \mathrm{~m}, 44 \mathrm{~m}$ above ground) and at the EC reference height $(54 \mathrm{~m})$ (Fig. 2). Temperature and humidity sensors were calibrated by the factory. The accuracy of the temperature sensors lies within a range of $\pm 0.3^{\circ} \mathrm{C}$. Measurements were controlled and stored by a data logger (CR1000, Campbell Scientific Inc., Loughborough, UK). Measurement interval was $10 \mathrm{sec}$ and averages were recorded every $30 \mathrm{~min}$. Additionally, we obtained meteorological data from the MeteoSwiss tower that is located on the Lägeren ridge $(868 \mathrm{~m}$ a.s.1.), $2.6 \mathrm{~km}$ east of our tower (MeteoSwiss, 2010). This point represents the highest measurement height of the vertical meteorological profile of $190 \mathrm{~m}$ above ground.

\subsection{EC data processing}

EC raw data are collected digitally at $20 \mathrm{~Hz}$ by an ACER notebook, running the in-house sonicreadHS software on a Linux operating system. 30 min averages of $\mathrm{CO}_{2}$ and water vapour fluxes are calculated off-line by the in-house software ethflux. Within this program, coordinate rotation is done by 2-D rotation (Mc Millen 1988), as the planar fit method was identified to be not suitable for the Lägeren site (Goeckede et al., 2008). Quality check of the data is performed by the standard procedure of the CarboEurope network (steadystate test and integral turbulence characteristics test), as described by (Foken and Wichura, 1996). More details about the processing procedure are given in Hiller et al. (2008). The ethflux software participated in the CarboEurope intercomparison of EC software (Mauder et al., 2008). In this study, different EC data processing software packages were compared to the reference software TK2 for different data sets. Differences between calculated fluxes with ethflux and TK2 over short vegetation are explained by the different coordinate rotation routine, as ethflux uses a 2-D rotation with block averaging, while TK2 is based on a planar fit transformation. However, over tall vegetation, the calculated fluxes agreed quite well (regression slope 0.97 to 1.06) and the ethflux estimates were only slightly larger.

The $30 \mathrm{~min} \mathrm{CO}_{2}$ flux averages were complemented with the change of $\mathrm{CO}_{2}$ storage below the measuring height of the EC instrumentation, derived from the ver- tical $\mathrm{CO}_{2}$ profile. Data were accepted if they met all of the following criteria: (1) window dirtiness (housekeeping variable provided by the Li-7500 open-path instrument) $<60 \%$, (2) $11 \mathrm{mmol} \mathrm{m}^{-3}<\mathrm{CO}_{2}$ concentration $<20 \mathrm{mmol} \mathrm{m}^{-3}$, (3) $-50 \mu \mathrm{mol} \mathrm{m}^{-2} \mathrm{~s}^{-1}<\mathrm{CO}_{2}$ flux $<$ $50 \mu \mathrm{mol} \mathrm{m} \mathrm{m}^{-2} \mathrm{~s}^{-1}$, (4) $-30 \mu \mathrm{mol} \mathrm{m} \mathrm{m}^{-2} \mathrm{~s}^{-1}<$ change of $\mathrm{CO}_{2}$ storage $<30 \mu \mathrm{mol} \mathrm{m}{ }^{-2} \mathrm{~s}^{-1}$, (5) $u^{\prime} w^{\prime}<0 \mathrm{~m}^{2} \mathrm{~s}^{-2}$ (Eugster et al., 2003, 2007), (6) quality flag $\leq 1$ (Foken and Wichura, 1996). Accepted data covered $63 \%$ of all available data.

\subsection{Gap-filling and partitioning}

To quantify the contribution of advection to the $\mathrm{C}$ budget, ecosystem fluxes, such as net ecosystem exchange (NEE), gross primary production (GPP) and ecosystem respiration (Reco) were calculated in three different ways: (1) from direct EC measurements $\left(F_{C}\right)$ without $\mathrm{u}_{*}$ filtering, (2) from direct EC measurements $\left(F_{C}\right)$, filtered by an $u_{*}$ threshold of $0.3 \mathrm{~m} \mathrm{~s}^{-1}\left(F_{C, u *}\right)$ and (3) from EC measurements that were complemented with (a) $F_{\mathrm{HA} 2 \mathrm{~m}}\left(F_{C, \mathrm{HA} 2 \mathrm{~m}}\right)$ and (b) $F_{\mathrm{HA} 2 \mathrm{~m}}$ and $F_{\mathrm{VA}}\left(F_{C, \mathrm{HA} 2 \mathrm{mVA}}\right)$ by incorporating each of the advection terms directly into the mass balance equation. Each data-set was subsequently gap-filled and partitioned into the gross fluxes, gross primary productivity (GPP) and ecosystem respiration (Reco) according to Reichstein et al. (2002, 2005). For further information about the gap-filling and fluxpartitioning procedure see also Moffat et al. (2007) and Falge et al. (2001). Finally, we obtained four different data sets of NEE, GPP and Reco, respectively: (1) $F_{C}$ unfiltered: NEE, GPP and Reco, (2) $F_{C}$ filtered by $u_{*}>0.3 \mathrm{~m} \mathrm{~s}^{-1}$ : $\mathrm{NEE}_{u *}, \mathrm{GPP}_{u *}, \mathrm{Reco}_{u *}$, (3) horizontal advection incorporated into the mass balance equation: $\mathrm{NEE}_{\mathrm{HA} 2 \mathrm{~m}}, \mathrm{GPP}_{\mathrm{HA} 2 \mathrm{~m}}$, $\mathrm{ReCO}_{\mathrm{HA} 2 \mathrm{~m}}$, and (4) horizontal and vertical advection incorporated into the mass balance equation: $\mathrm{NEE}_{\mathrm{HA} 2 \mathrm{mVA}}$, $\mathrm{GPP}_{\mathrm{HA} 2 \mathrm{mVA}}$, Reco $\mathrm{HA} 2 \mathrm{mVA}$.

By convention, fluxes directed from the atmosphere to the biosphere are denoted with a negative sign, from the biosphere to the atmosphere with a positive sign.

\subsection{Validation measurements}

\subsubsection{Soil respiration}

Soil respiration (SR) chamber measurements were carried out campaign-wise during May to August 2007 at 17 plots within the EC flux tower footprint. Data were gap-filled and modeled based on temperature response functions. Details about measurement routine and data treatment can be found in Rühr et al. (2009).

\subsubsection{Respiration derived from light response curves}

An independent daily average of respiration was derived from the extrapolation of light response curves to zero light. The response of day-time NEE to PPFD was modeled within 
a ten-day moving window using a logistic sigmoid function (Moffat, 2010):

$\mathrm{NEE}=2 F_{\text {inf }}\left(\frac{1}{2}-\frac{1}{\left(1+e^{-2 \alpha \frac{\mathrm{PPFD}}{F_{\text {inf }}}}\right)}\right)+R$

with $F_{\text {inf }}=$ maximal ecosystem photosynthetic capacity $\left[\mu \mathrm{mol} \mathrm{CO} \mathrm{C}^{-2} \mathrm{~s}^{-1}\right], \quad \mathrm{PPFD}=$ photosynthetically active radiation $\left[\mu \mathrm{mol}\right.$ photons $\left.\mathrm{m}^{-2} \mathrm{~s}^{-1}\right], \quad R=$ respiration term $\left[\mu \mathrm{mol} \mathrm{CO} \mathrm{C}_{2}^{-2} \mathrm{~s}^{-1}\right]$ and $\alpha=$ initial quantum yield.

\subsubsection{Energy Budget Closure}

The surface energy budget is defined as:

$R_{\mathrm{n}}-G-S=\mathrm{LE}+H+\Delta Q$,

with $R_{\mathrm{n}}=$ net radiation, $G=$ soil heat flux, $S=$ canopy heat storage, $\mathrm{LE}=$ latent heat flux, $H=$ sensible heat flux, $\Delta Q=$ energy budget closure gap. The magnitude of the energy budget closure is used as an independent evaluation of the performance of EC flux estimates (Aubinet et al., 2000; Wilson et al., 2002). The energy balance ratio (EBR) gives an overall evaluation of the energy balance closure at longer time scales and is defined as:

$\mathrm{EBR}=\frac{\sum(\mathrm{LE}+H)}{\sum\left(R_{\mathrm{n}}-G-S\right)}$.

Sensible and latent heat flux were derived from EC measurements. Canopy heat storage was not assessed at the Lägeren forest. According to Wilson et al. (2002), it attributes about $7 \%$ to the EBR at forested sites. Due to technical failure of our data logger, no reliable data for ground heat flux could be obtained during five weeks in summer 2007. For this period, we estimated soil heat flux as a fraction of $R_{\mathrm{n}}$ derived from available data (see e.g., Eugster et al., 1997). In general, soil heat flux is about $2 \%$ of $R_{\mathrm{n}}$. Thus, the uncertainty in our estimates of $\mathrm{G}$ should not be of any importance in the context of this study.

All calculations and statistical analyses were carried out with the statistics software package R, version 2.4.1 (R Development Core Team, 2006). Outliers in variable $\mathrm{x}$ were defined as values outside the $\pm 3 \sigma$ range of the empirical distribution of $\mathrm{x}$.

\section{Results}

\subsection{Advection patterns}

Wind regimes above $(54 \mathrm{~m})$ and inside $(1 \mathrm{~m})$ the canopy were totally uncoupled for both unstable and stable conditions (unstable: $z / L<0$, stable and neutral: $z / L \geq 0$, where $z / L$ is the Monin-Obukhov stability parameter) (Fig. 3). Above the canopy, the wind was oriented along the ridge of the Jura

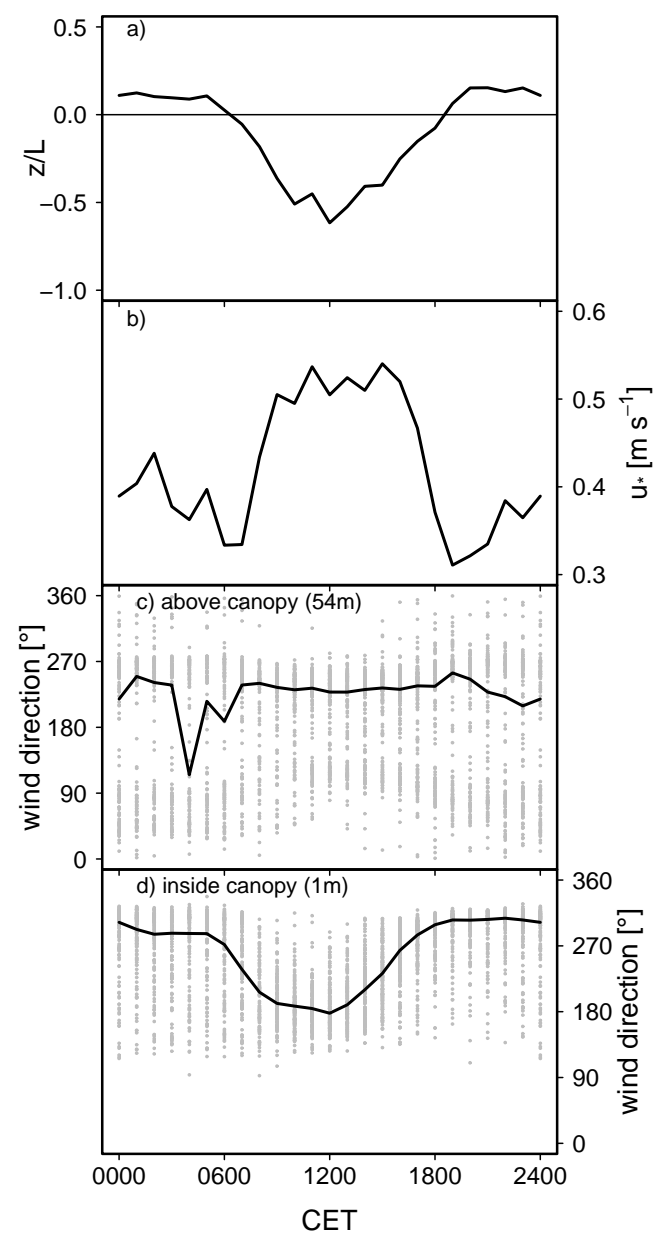

Fig. 4. Median diurnal cycles of (a) stability parameter $z / L$, (b) friction velocity $u_{*}$ at EC height (54 m) during May to August 2007. Half-hourly values (grey points) and median hourly values (solid line) of wind direction at (c) EC height $(54 \mathrm{~m})$ and (d) inside the canopy $(1 \mathrm{~m})$.

mountain most of the time (West-East direction, Figs. 1 and 3 ). In the canopy, however, the wind regime was dominated by a persistent local slope wind system with up-slope winds (South-East: $170^{\circ}$ ) during unstable conditions and downslope wind (North-West: $315^{\circ}$ ) during stable conditions.

Stable stratification dominated during the night, leading to a pronounced diurnal cycle of the stability parameter $z / L$, friction velocity $u_{*}$ and wind direction in the canopy (Fig. 4). However, although values of $z / L$ were positive during night, its magnitude was comparatively small (on average $<0.2$ ), while $u_{*}$, though decreasing at night, was still relatively high $\left(0.3-0.4 \mathrm{~m} \mathrm{~s}^{-1}\right)$, indicating good turbulent mixing and representativeness of the EC flux measurements.

All three vertical profiles (mean horizontal wind speed and air temperature, as well as $\mathrm{CO}_{2}$ concentration) showed same patterns under unstable and stable conditions (Fig. 5). In general, wind speeds inside the canopy were relatively small, 

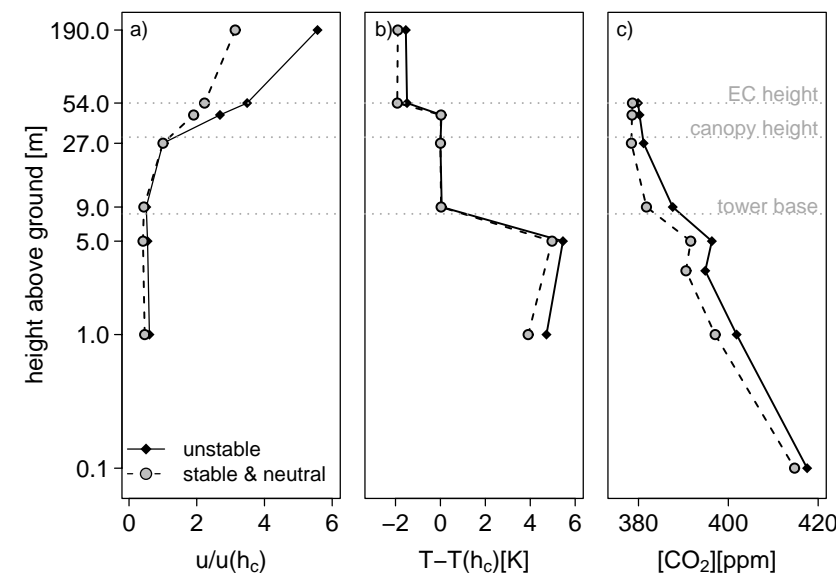

Fig. 5. Vertical profiles for two stability classes (unstable and neutral/stable) during May to August 2007 of (a) mean horizontal wind speed normalized by wind speed at canopy height $\left(\mathrm{h}_{c}=30 \mathrm{~m}\right),(\mathbf{b})$ mean difference of air temperature and air temperature at canopy height and c) mean $\mathrm{CO}_{2}$ concentrations. Solid black lines indicate unstable conditions, dotted lines and grey points stable and neutral conditions. The data point at $190 \mathrm{~m}$ above ground was derived from the MeteoSwiss tower at the Lägeren ridge.

increasing above the canopy, thus creating a wind speed profile that was nearly logarithmic with height (Fig. 5a). The kink at $5 \mathrm{~m}$ height within the temperature profile (Fig. 5b) can be attributed to the measurement set-up of the staggered meteorological profile, and will not be discussed further. The constant temperatures across the canopy however indicate good turbulent mixing of the air and development of just a shallow drainage layer. This was also confirmed by the vertical $\mathrm{CO}_{2}$ concentration profile (Figs. $5 \mathrm{c}$ and 6 ). $\mathrm{CO}_{2}$ concentrations across the canopy as well as the $\mathrm{CO}_{2}$ flux at EC height showed large diurnal changes during ten representative days in June 2007, but only little vertical variation of $\mathrm{CO}_{2}$ concentrations inside the canopy, indicating substantial vertical mixing. Thus, $\mathrm{CO}_{2}$ gradients occurred mainly below $10 \mathrm{~m}$ height and were most pronounced below $2 \mathrm{~m}$.

$\mathrm{CO}_{2}$ fluxes followed closely the diurnal pattern of the $\mathrm{CO}_{2}$ concentrations (Fig. 6): During the night $\mathrm{CO}_{2}$ accumulated in the canopy due to respiration and low turbulence conditions (Fig. 7a). The onset of turbulence and plant assimilation in the morning stopped $\mathrm{CO}_{2}$ accumulation and led to the typical $\mathrm{CO}_{2}$ depletion during the day-light hours. The canopy storage term was negative during day $\left(\mathrm{CO}_{2}\right.$ was removed from the storage) and positive during night $\left(\mathrm{CO}_{2}\right.$ was added to the storage). However, during the first half of the night, the storage term decreased. Assuming constant $\mathrm{CO}_{2}$ release by plants and soils during the night (Aubinet et al., 2005; Van Gorsel et al., 2007) and the decrease of turbulent mixing, indicated by the decreasing $u_{*}$ values, as well as the change of the wind direction in canopy (Fig. 4), the decrease of the storage term in the first half of the night might

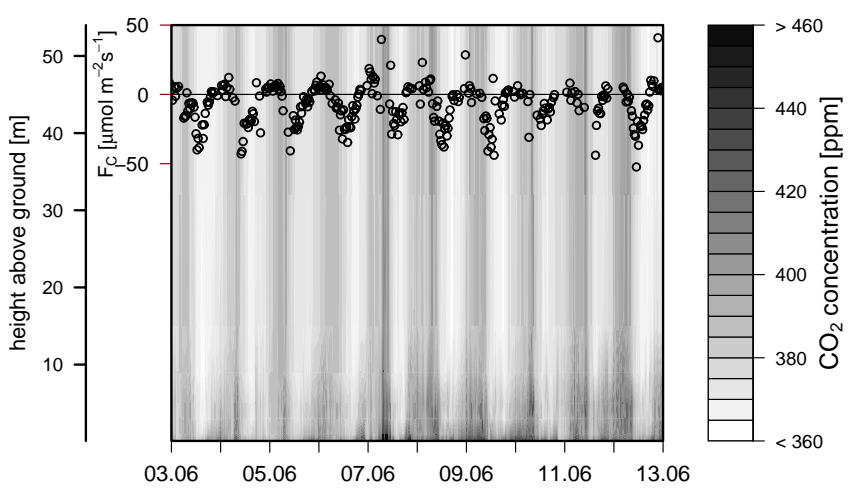

Fig. 6. Vertical profile of $\mathrm{CO}_{2}$ concentrations and $\mathrm{CO}_{2}$ flux during ten days in June 2007. The inset with open circles shows the net $\mathrm{CO}_{2}$ flux measured by EC (30-min averages). Mean canopy height is $30 \mathrm{~m}$.

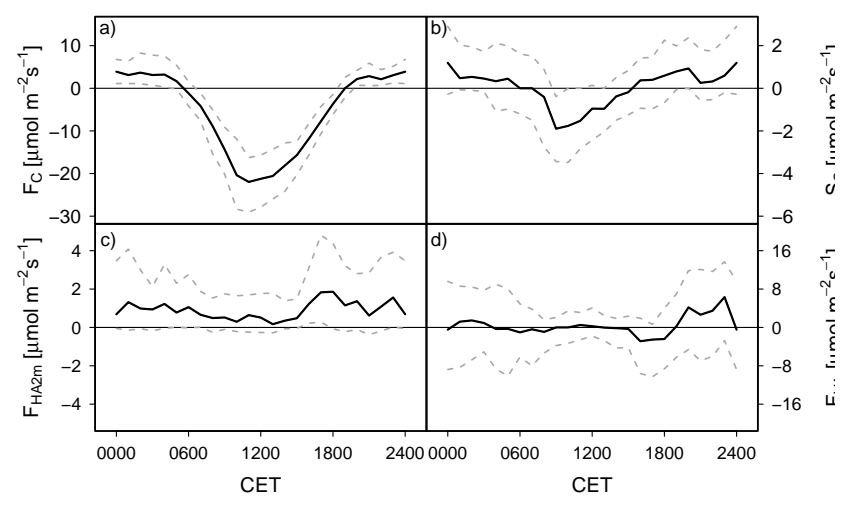

Fig. 7. Diurnal cycles of (a) $\mathrm{CO}_{2}$ flux $\mathrm{F}_{C}$, (b) storage term $\mathrm{S}_{C}$, (c) horizontal advection $\mathrm{F}_{\mathrm{HA} 2 \mathrm{~m}}$ and (d) vertical advection $\mathrm{F}_{V A}$ for the period of May to August 2007. Black lines indicate median values, grey broken lines inter quantiles $(25 \%, 75 \%)$ of the respective fluxes. Note that y axes are different scales.

be attributed to non-turbulent fluxes, probably drainage flow. This interpretation is consistent with drainage horizontal advection $\left(F_{\mathrm{HA} 2 \mathrm{~m}}\right)$ peaking in the early evening (Fig. $\left.7 \mathrm{c}\right)$, exactly when $u_{*}$ reached its minimum and $z / L$ became positive (Fig. 4). That is, turbulent exchange was decreasing and the inversion layer was growing as the atmosphere became stable and the near surface winds completely aligned with the slope.

Although both advective fluxes showed a broad scatter, diurnal trends were found (Fig. $7 \mathrm{c}, \mathrm{d}$ ). Positive $F_{\mathrm{HA} 2 \mathrm{~m}}$ during night resulted generally from down-slope winds $\left(u_{c}>0\right)$ and a positive $\mathrm{CO}_{2}$ gradient with higher $\mathrm{CO}_{2}$ concentrations down slope $\left(\frac{\partial \bar{c}}{\partial x}>0\right)$, whereas during the day up-slope winds $\left(u_{c}<0\right)$ and a negative $\mathrm{CO}_{2}$ gradient $\left(\frac{\partial \bar{c}}{\partial x}<0\right)$ predominated. Vertical advection fluxes $\left(F_{\mathrm{VA}}\right)$ were larger than $F_{\mathrm{HA} 2 \mathrm{~m}}$ and highly variable (Fig. 7d; note the different vertical scales). During the night, high positive and negative values were 
Table 1. Mean daily fluxes of EC fluxes $\left(F_{C}\right)$, storage term $\left(S_{C}\right)$, drainage horizontal advection $\left(F_{\mathrm{HA} 2 \mathrm{~m}}\right)$ and vertical advection $\left(F_{\mathrm{VA}}\right)$ for the period May to August 2007. Day-time was defined as 06:00-18:00 CET, night-time as 19:00-05:00 CET.

\begin{tabular}{lccc}
\hline & \multicolumn{3}{c}{ mean daily flux $\left[\mu \mathrm{mol} \mathrm{m}^{-2} \mathrm{~s}^{-1}\right]$} \\
\hline & day-time & night-time & all \\
$F_{C}$ & -11.4 & 3.02 & -6.13 \\
$S_{C}$ & -0.36 & 0.67 & 0.02 \\
$F_{\text {HA2m }}$ & 1.10 & 1.68 & 1.31 \\
$F_{\text {VA }}$ & -1.60 & 1.26 & -0.34 \\
\hline
\end{tabular}

observed and the scatter was pronounced and sometimes more erratic. During the day, when vertical $\mathrm{CO}_{2}$ gradients were small, advective fluxes fluctuated around zero. On a daily basis, $F_{\mathrm{VA}}$ summed up to relatively small values due to the counteracting fluxes in both directions (Table 1). Diurnal patterns of both advective fluxes could be explained by the local wind system. As frequently observed over steep slopes, development of gravity flows through the forest understory due to surface radiative cooling in the evening caused a negative vertical flow and entrainment of air from above canopy to the soil. Early in the evening gravity flows started to develop (1600 CET, $u_{c}<0$ changed to $\left.u_{c}>0\right)$ and the stable nocturnal boundary layer (SNBL) started to grow. Vertical velocity $\bar{w}$ was positive during the day (upward) and started to decrease sharply exactly when $u_{c}$ has reached its maximum in down-slope direction (1800 CET). That is, the growing SNBL over the valley floor has reached the site's elevation and air from above the canopy is entrained into the control volume, following the gravity flow through the forest understory $(\bar{w}<0)$. This is confirmed by the fact that highest positive $F_{\mathrm{VA}}$ occur when wind direction in the canopy is in down-slope direction (290-340 ) (data not shown). The negative peak of $F_{\mathrm{VA}}$ around 1700 CET (Fig. 7d) resulted from a still positive $\bar{w}$ and the increasing negative vertical $\mathrm{CO}_{2}$ gradient due to decreased mixing of the air.

Positive advection during night leads to depletion of $\mathrm{CO}_{2}$ inside the control volume and consequently to an underestimation of the respiration flux by the EC instrumentation above the canopy. Thus, adding advective fluxes to $F_{C}$ should theoretically correct for the underestimation of respiration during the night. Due to erratically large fluxes of $F_{\mathrm{VA}}$ in both directions, correcting of $F_{C}$ for $F_{\mathrm{VA}}$ resulted in unrealistic fluxes with respect to magnitude and sign, e.g. negative fluxes during night. Thus, for further analyses we eliminated those fluxes by discarding those at the lowest and the highest boundary (10\%).

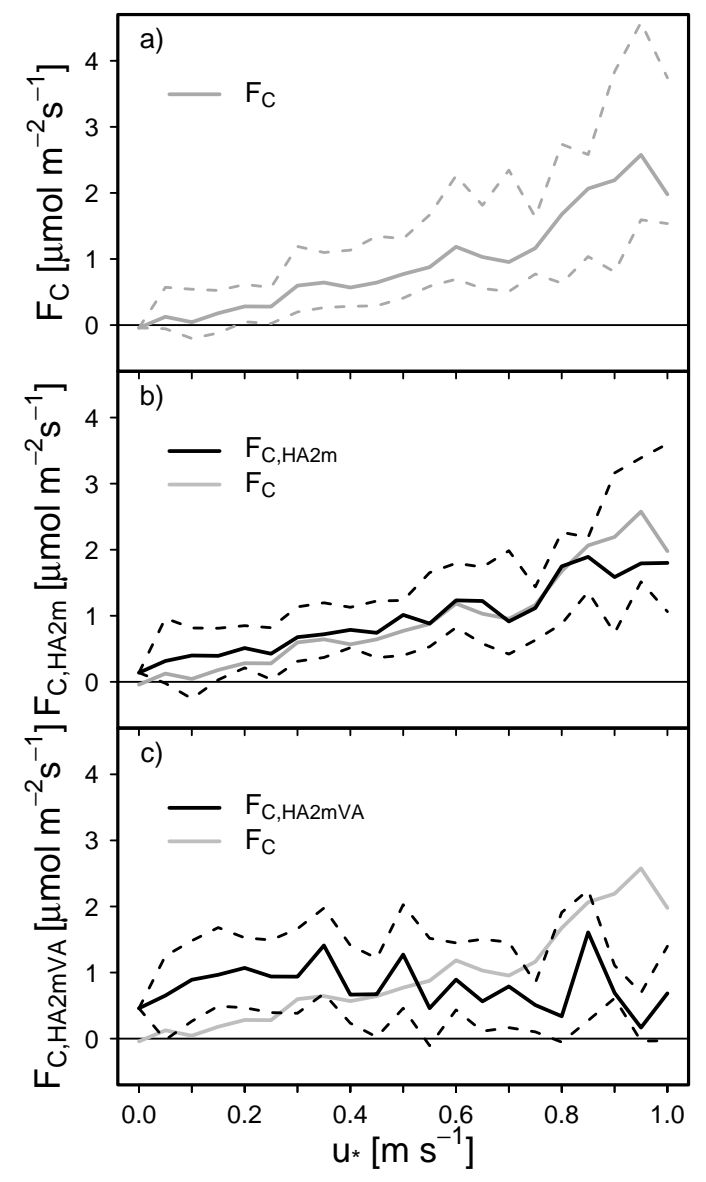

Fig. 8. Relationships of (a) night-time $\mathrm{F}_{C}$, normalized to $10^{\circ} \mathrm{C}$ by the temperature response function according to Lloyd \& Taylor (1994), (b) $\mathrm{F}_{C, \mathrm{HA} 2 \mathrm{~m}}$ and (c) $\mathrm{F}_{C, \mathrm{HA} 2 \mathrm{mVA}}$ to classes of friction velocity $\mathrm{u}_{*}$ for the period of May to August 2007. Black solid lines indicate the median, black broken lines the inter quantiles $(25 \%$, $75 \%$ ) for the respective flux.

\subsection{Contribution of advection to $\mathrm{C}$ budget}

Night-time $\mathrm{CO}_{2}$ fluxes that were normalised to $10^{\circ} \mathrm{C}$ increased constantly with increasing $u_{*}$ (Fig. 8a). Thus, by visual examination no $u_{*}$ threshold could be identified at which the night-time $\mathrm{CO}_{2}$ fluxes remained constant. Adding $F_{\mathrm{HA} 2 \mathrm{~m}}$ to the measured EC values increased night-time fluxes at low $u_{*}$ values, but showed no effect for higher $u_{*}$ values and a decrease for $u_{*}>0.8 \mathrm{~m} \mathrm{~s}^{-1}$ (Fig. 8b). Night-time fluxes, derived form EC measurements and both advective fluxes incorporated into the mass balance showed no dependency on $u_{*}$ any longer (Fig. 8c). On a daily basis $F_{\mathrm{VA}}$ summed up to almost zero (Fig. 7, Table 1). Therefore, it could be argued that over longer time scales (daily, seasonal, yearly) $F_{\mathrm{VA}}$ is not relevant for the site's $\mathrm{C}$ budget, whereas $F_{\mathrm{HA} 2 \mathrm{~m}}$ is, being predominantly positive and most significant at low $u_{*}$. In fact, EC fluxes that were corrected only for $F_{\mathrm{HA} 2 \mathrm{~m}}$ showed good agreement to the $u_{*}$ filtered data 
Table 2. Cumulative sums of NEE, GPP and Reco for May to August 2007 based on EC data and different correction approaches for the forest site Lägeren.

\begin{tabular}{|c|c|c|c|c|c|c|c|c|c|}
\hline \multirow[t]{2}{*}{$\mathrm{EC}$} & \multicolumn{2}{|c|}{$\mathrm{EC}\left(u_{*} \geq 0.3\right)$} & \multicolumn{2}{|c|}{$\mathrm{EC}\left(\mathrm{NEE}+F_{\mathrm{HA} 2 \mathrm{~m}}\right)$} & \multicolumn{2}{|c|}{$\mathrm{EC}\left(\mathrm{NEE}+F_{\mathrm{HA} 2 \mathrm{~m}}+F_{\mathrm{VA}}\right)$} & \multirow{2}{*}{$\begin{array}{l}\text { LRC } \\
b^{(b)}\end{array}$} & \multirow[t]{2}{*}{ SR } & \\
\hline & $\Sigma^{(\mathrm{a})}$ & $\Sigma^{(\mathrm{a})}$ & $b^{(b)}$ & $\Sigma^{(\mathrm{a})}$ & $b^{(b)}$ & $\Sigma^{(\mathrm{a})}$ & & & \\
\hline $\mathrm{NEE}\left[\mathrm{g} \mathrm{C} \mathrm{m}^{-2}\right]$ & -442 & -308 & 0.69 & -285 & 0.65 & -513 & 1.16 & - & - \\
\hline $\mathrm{GPP}\left[\mathrm{g} \mathrm{C} \mathrm{m}^{-2}\right]$ & -1050 & -1209 & 1.15 & -1080 & 1.03 & -1326 & 1.26 & - & - \\
\hline $\operatorname{Reco}\left[\mathrm{g} \mathrm{C} \mathrm{m}^{-2}\right]$ & 608 & 902 & 1.48 & 795 & 1.31 & 814 & 1.34 & 653 & 456 \\
\hline
\end{tabular}

(a) Cumulative sums of NEE, GPP and Reco for May to August 2007 [ $\left.\mathrm{g} \mathrm{C} \mathrm{m}^{-2}\right]$.

(b) $b=$ Percentage of cumulative sum of NEE, GPP and Reco of direct EC measurements (EC) in relation to the respective sum of the other variants.

(linear regression with $\operatorname{Reco}_{u *}$ : slope: $0.78 \pm 0.04$, intercept: $0.68 \pm 0.29 \mu \mathrm{mol} \mathrm{m}{ }^{-2} \mathrm{~s}^{-1}$, adj. $\left.R^{2}=0.78, p<0.001\right)$. Estimated respiration loss between May to August 2007 was $12 \%$ higher for $\operatorname{Reco}_{u *}\left(906 \mathrm{~g} \mathrm{C} \mathrm{m}^{-2}\right)$ than for $\mathrm{RecO}_{\mathrm{HA}} 2 \mathrm{~m}$ (795 $\mathrm{g} \mathrm{C} \mathrm{m}^{-2}$ ) (Table 2). Substantial differences occurred in June, with much higher respiration values for $\operatorname{Reco}_{u *}$. This was due to the fact that during that period of ten days $43 \%$ of night-time data were below the $u_{*}$ threshold of $0.3 \mathrm{~m} \mathrm{~s}^{-1}$, although $F_{\text {HA2m }}$ was not very pronounced. A temperature peak led then to the large modeled respiration fluxes. Accounting for advection by the $u_{*}$ filter resulted in $48 \%$ higher cumulative $\operatorname{Reco}_{u *}$ during May to August 2007 compared to Reco (Table 2), and questions whether replacing measured data by model results is the best possible approach to quantify ecosystem respiration. To answer this question, we validated our suggestions to (a) quantify advection via a simplified 2-D measurement approach, and (b) approximate these advection corrections with a $u_{*}$ threshold of $0.3 \mathrm{~m} \mathrm{~s}^{-1}$. Three independent approaches support our findings as reported in the following.

\subsection{Validation of EC flux corrections}

\subsubsection{Soil respiration}

Soil respiration (SR, Fig. 9) chamber measurements (Rühr et al., 2009) were correlated with RecoHA2m $(R=0.43)$ and $\operatorname{Reco}_{u *}(R=0.50)$ with a time lag of -1 day. This is a better correlation than what was found with uncorrected $\operatorname{Reco}(R=$ 0.22 ). Over the whole measurement period, SR contributed about $50 \%$ to $\operatorname{Reco}_{u *}$ (Table 2), monthly contribution of SR to $\mathrm{Reco}_{u *}$ ranged from $43 \%$ in May, over $50 \%$ in summer and to $76 \%$ in August.

\subsubsection{Light response curves}

Daily respiration estimates that can be extracted from light response curve (LRC) intercepts (e.g., Moffat et al., 2007) were well correlated with daily means of respiration rates obtained directly by nocturnal EC measurements $(R=0.78)$, with those filtered by $u_{*}, \operatorname{Reco}_{u *}(R=0.68)$, and with those

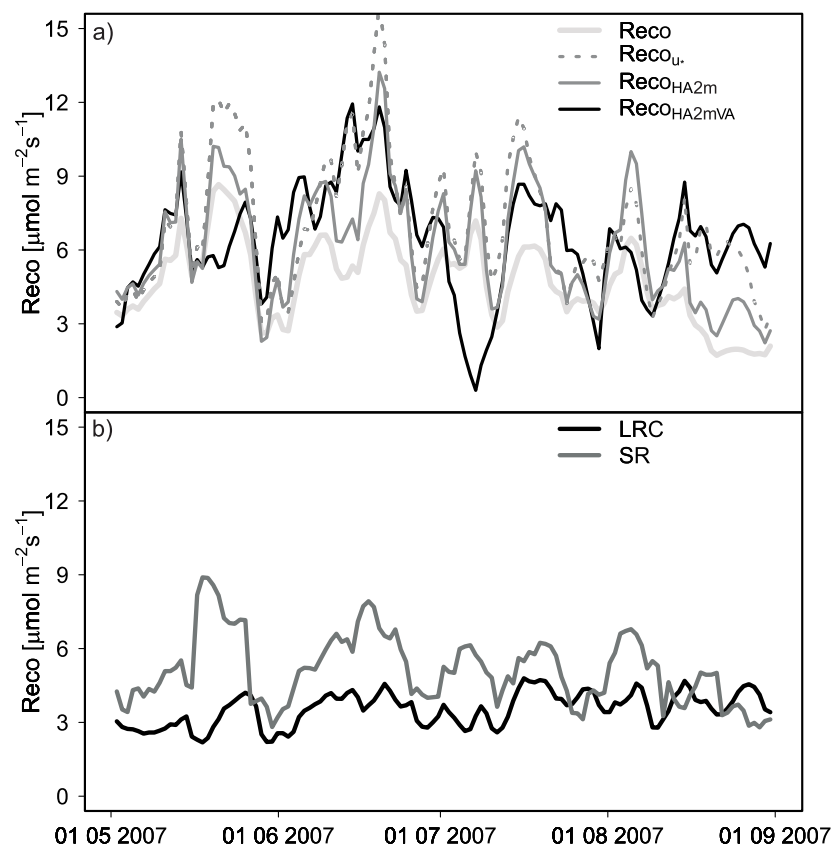

Fig. 9. (a) Daily medians of Reco for the period from May to August 2007. Reco is derived according to Reichstein et al. (2002, 2005) from (1) direct EC measurements (Reco), (2) filtered by $u_{*} \geq 0.3\left(\operatorname{Reco}_{u *}\right)$, (3) by incorporating (a) $F_{\mathrm{HA} 2 \mathrm{~m}}\left(\operatorname{Reco}_{\mathrm{HA} 2 \mathrm{~m}}\right)$ and (b) $F_{\mathrm{HA} 2 \mathrm{~m}}$ and $F_{\mathrm{VA}}$ (Reco HA2mVA) into the mass balance equation. (b) Daily median respiration values derived from soil respiration chamber measurements (SR) and light response curves (LRC).

corrected for horizontal advection RecoHA2m $(R=0.69)$. The cumulated sum for the period May to August based on the LRC approach was lower $\left(653 \mathrm{~g} \mathrm{C} \mathrm{m}^{-2}\right)$ than $\operatorname{Reco}_{u *}$ and RecoHA (Table 2).

\subsubsection{Energy budget closure}

For the Lägeren forest, linear regression of the sum of turbulent heat fluxes to available energy for the period from May to August 2007 resulted in a slope of $0.78 \pm 0.01$ and 


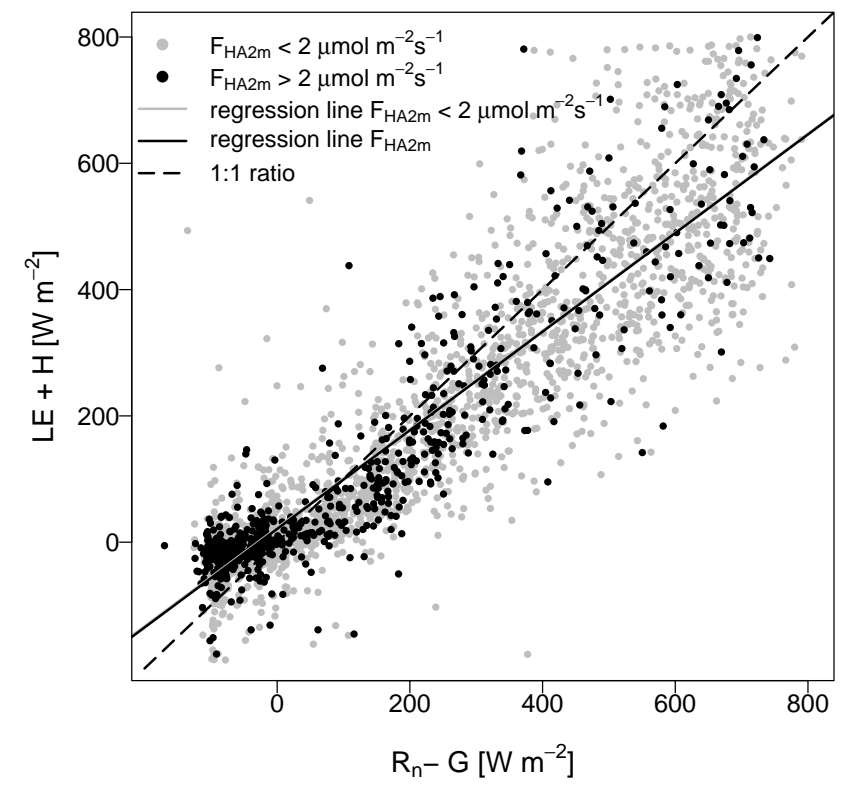

Fig. 10. Relationship between available energy (net radiation $R_{\mathrm{n}}-$ ground heat flux $G$ ) and turbulent fluxes (latent heat LE and sensible heat $H$ ) for the period from May to August 2007. Grey circles indicate data points with advection $<2 \mu \mathrm{mol} \mathrm{m} \mathrm{m}^{-2} \mathrm{~s}^{-1}$, black circles represent data points with horizontal advection $>2 \mu \mathrm{mol} \mathrm{m}^{-2} \mathrm{~s}^{-1}$. The 1:1 regression line is given in grey. The regression lines of the data points are given in black and as they are nearly congruent appear as one single line.

an intercept of $22.9 \pm 2.0\left(\right.$ adj. $R^{2}=0.84$, (Fig. 10), the EBR yielded 0.86 . Under the assumption that advection impacts the accuracy of EC measurements, a higher energy budget closure should be reached by excluding data periods when high advection occurred. However, neither exclusion of periods with $F_{\mathrm{HA} 2 \mathrm{~m}}>2 \mu \mathrm{mol} \mathrm{m}{ }^{-2} \mathrm{~s}^{-1}(26.7 \%)$ was improving the energy budget closure at our site (slope: $0.77 \pm 0.01$, intercept: $20.0 \pm 2.8$, adj. $R^{2}=0.82$ ), nor the exclusion of $F_{\mathrm{VA}}$ outside the range of $\pm 10 \mu \mathrm{mol} \mathrm{m} \mathrm{m}^{-2} \mathrm{~s}^{-1}$ (regression slope: $0.77 \pm 0.01$, intercept: $20.2 \pm 3.1$, adj. $R^{2}=0.82$ ).

\section{Discussion}

$F_{\mathrm{HA} 2 \mathrm{~m}}$ and $F_{\mathrm{VA}}$ at the Lägeren site showed different patterns. $F_{\mathrm{VA}}$ were much larger than $F_{\mathrm{HA} 2 \mathrm{~m}}$ and showed a broad scatter and an erratic behaviour, but over the course of a day positive and negative $F_{\mathrm{VA}}$ summed up to almost zero. $F_{\mathrm{HA} 2 \mathrm{~m}}$ was throughout positive and much more directional and systematic, following the diurnal mountain wind system. Whereas $F_{\mathrm{HA} 2 \mathrm{~m}}$ was caught very well by the $u_{*}$ filter, $F_{\mathrm{VA}}$ produced unrealistic high fluxes when incorporated into the mass balance equation. In our discussion, we will focus on the following aspects that are of concern at almost any EC flux site: (1) our attempt to simplify the experimental set-up to quantify horizontal advection and its representativeness; (2) how important advection is for long-term $\mathrm{C}$ budgets and how it relates to the simpler but entirely empirical $u_{*}$ correction and (3) how these estimates are linked to independently derived validation data.

\subsection{Quantification of advection with a simple 2-D approach}

Several studies have been published so far where advection was measured by multiple EC towers in a complex threedimensional multi-level set-up (e.g., Staebler and Fitzjarrald, 2004; Heinesch et al., 2007; Feigenwinter et al., 2008; Leuning et al., 2008; Yi et al., 2008). However, this is not a practicable option for most of the flux tower sites. But, the occurrence of advection seems to be rather the rule than the exception, whereas its quantitative relevance in relation to turbulent fluxes is not known a priori at a given flux tower site. The best available knowledge presented in recent publications suggests that the quantitative relevance of advective fluxes should at least be tested at long-term EC flux sites, since no generally applicable rules could be derived from extensive field experiments on advection so far. Therefore we tested a relatively simple set-up for advection measurements based on the current knowledge of advection. It is well-known that cold-air drainage flow is very common at mountain sites due to local valley and slope wind systems (Wagner, 1938; Defant, 1949; Whiteman and Doran, 1993; Whiteman, 2000). This was confirmed at our study site, where wind field analyses showed strongly channeled winds above canopy and a pronounced diurnal cycle of wind directions inside the canopy. This 2 -D character of the wind system gives the opportunity to reduce advection measurements to a 2-D approach, namely along the prevailing wind direction in canopy. With this simplification an error of the $F_{\mathrm{HA}}$ assessment up to $5 \%$ is made as long as the deviation of the true wind flow and the hypothetical two-dimensional gradient $\beta<12.6^{\circ}$, and it is within $10 \%$ if $\beta<17.5^{\circ}$ (see Final Response).

Total $F_{\mathrm{HA}}$ strongly depends on the chosen integration height: slight modifications of the integration height can result in large changes of the advection flux. According to Finnigan et al. (2003), a vertical integral of the non-turbulent horizontal flux divergence is necessary to close the mass budget. However, to achieve this, a multi-level set-up with all necessary measurements would be required. But as this is not practicable at most sites, the integration height is usually estimated by integrating or modeling the vertical wind, temperature and $\mathrm{CO}_{2}$ concentration profiles (Aubinet et al., 2003; Feigenwinter et al., 2004; Kutsch et al., 2009). However, this can be relatively speculative. For example, we computed $F_{\mathrm{HA} 2 \mathrm{~m}}$ along the prevailing wind direction for a layer depth of $2 \mathrm{~m}$ according to the measurement height of $\mathrm{CO}_{2}$ gradients and wind vectors. It is thus possible that $F_{\mathrm{HA}}$ in total might be larger than the presented values. However, our vertical profiles of horizontal wind speed, temperature and 
$\mathrm{CO}_{2}$ concentrations (Figs. 5 and 6) suggest that the drainage layer is relatively shallow due to a strong nocturnal gravitational flow along the steep slope. Thus, $F_{\mathrm{HA}}$ is most pronounced very close to the ground surface. Displacement of the $\mathrm{CO}_{2}$ measurements to a height of $2 \mathrm{~m}$ in 2008 showed indeed a decreased horizontal $\mathrm{CO}_{2}$ gradient (about 50\% compared to $1 \mathrm{~m}$ ), whereas horizontal wind speed remained unchanged (data not shown). Thus, an integration height larger than $2 \mathrm{~m}$ would not have been representative for our measurements and most likely would have led to an overestimation of the horizontal advection term. Gradient measurements carried out in 2008 and 2009 at 1 and $2 \mathrm{~m}$ above the ground and with one additional point in between our horizontal gradient (at distances 0, 12,60 m) confirmed the observed patterns of horizontal advection as described above and showed repeatable characteristics. Therefore, we are convinced that the horizontal advection term as presented in this study is temporally and spatially valid, at least with regard to the vertical dimension. $F_{\mathrm{HA} 2 \mathrm{~m}}$, obtained by this simple set-up, showed characteristic, well-known patterns, such as the pronounced diurnal cycle that closely follows the local wind system (Whiteman, 2000). Derived values are robust and well in the range of other studies that were conducted on sloping terrain (Marcolla et al., 2005; Feigenwinter et al., 2008).

\subsection{Contribution of advection to $\mathrm{C}$ budget}

Incorporation of advective fluxes directly into the mass balance equation is a highly controversial issue in the scientific discussion and was already addressed by several authors (see Aubinet et al., 2010). Analysing advection measurements of three different sites, Aubinet et al. (2010) concluded that advection can not be included "one to one" into the mass balance due to different measurement scales of advection and EC fluxes and too low spatial resolution of advection measurements. Physical correction of EC fluxes at the Lägeren site by measured horizontal and vertical advection was of differing quality. Incorporating both advection terms directly into the mass balance, produced unrealistic biotic fluxes, e.g., negative fluxes during the night, and could mainly be attributed to the vertical advection term. But on a longer term basis, horizontal advection is assumed to have the biggest influence on the $\mathrm{C}$ budget of the Lägeren site, whereas $F_{\mathrm{VA}}$ seems to be of minor importance as fluxes, integrated over longer time scales, counterbalance themselves to almost zero. In contrast to this, Aubinet et al. (2010) identified $F_{\mathrm{VA}}$ to be the major problem for their three investigated sites. The Lägeren forest fixed $157 \mathrm{~g} \mathrm{C} \mathrm{m}^{-2}$ less than what direct EC measurements suggested over the observation period of four months when involving $F_{\mathrm{HA} 2 \mathrm{~m}}$ into calculations. Thus, $F_{\mathrm{HA} 2 \mathrm{~m}}$ accounted for $36 \%$ of the ecosystem's C budget. As $F_{\mathrm{HA}}$ is most prominent during the growing season (data not shown; cf., Yi et al., 2008) and the respiration flux is usually highest during summer time, we deduce that $F_{\mathrm{HA} 2 \mathrm{~m}}$ only plays a minor role during the dormant season. Thus, on an annual basis, $F_{\mathrm{HA} 2 \mathrm{~m}}$ should not exceed $36 \%$ of NEE.

The correction of night-time NEE data by the $u_{*}$ filter approach is recommended as the method of choice by Aubinet (2008). Many studies have shown that the rejection of periods with low $u_{*}$ values result in a systematic decrease of annual sums of NEE in the order of 50 to $200 \mathrm{~g} \mathrm{C} \mathrm{m}^{-2} \mathrm{a}^{-1}$ (e.g., Falge et al., 2001; Carrara et al., 2003; Hui et al., 2004). Hereby, the decrease of NEE is a direct function of the choice made for the $u_{*}$ threshold. In our case, calculations involving $u_{*}$ filtering yielded $107 \mathrm{~g} \mathrm{C} \mathrm{m}^{-2}$ lower carbon uptake during May to August than EC measurements suggested. Data that were filtered by a $u_{*}$ threshold of $0.3 \mathrm{~m} \mathrm{~s}^{-1}$ showed good agreement to those, for which $F_{\mathrm{HA} 2 \mathrm{~m}}$ was incorporated into the mass balance equation, with a deviation of the seasonal sums smaller than $12 \%$. We found that a $u_{*}$ filter with a threshold of $0.3 \mathrm{~m} \mathrm{~s}^{-1}$ gives a good estimate of Reco for our study site. However, the simpler $u_{*}$ filtering approach is purely empirical and at times it is unclear why there are large discrepancies between $F_{\mathrm{HA}}$ and the $u_{*}$ derived respiration flux (e.g., Fig. 9, in June). Although horizontal advection and $u_{*}$ were reasonably correlated, especially at lower $u_{*}$ values (Fig. 8b), no overall firm relationship of hourly or daily values of advection to $u_{*}$ could be established. This decoupling between advection and $u_{*}$ was also observed in other studies (Marcolla et al., 2005; Yi et al., 2008; Kutsch et al., 2009).

\subsection{Validation of EC flux corrections}

In order to validate our various correction approaches we related the calculated fluxes to independently derived measurements. Soil respiration chamber measurements (Rühr et al., 2009) are in line with $\operatorname{Reco}_{u *}$ and Reco HA2m. Seasonal $(50 \%)$ as well as monthly contributions of SR to $\operatorname{Reco}_{u *}$ and Reco $\mathrm{HA}_{2 \mathrm{~m}}$ (40\% in spring, 76\% in late summer) are well in the range of values reported earlier ( 40 to $80 \%$ with increasing contribution from spring to fall (e.g., Curiel Yuste et al., 2005; Davidson et al., 2006)).

Also, daily respiration estimates that were derived from extrapolation of light response curves to zero light showed good agreement to our Reco $\operatorname{R}_{u *}$ and Reco $\mathrm{HA}_{2 \mathrm{~m}}$ estimates $(r=$ $0.68, r=0.67)$, but values were lower and closer to the uncorrected Reco values. Underestimation of ecosystem respiration derived from daytime data up to $20 \%$ was already reported for similar comparisons of respiration estimates and attributed to inhibition of canopy respiration during daytime, footprint differences between day and night-time and differences between short term autotrophic carbon loss and longer term heterotrophic carbon loss (e.g., Falge et al., 2002; Xu and Baldocchi, 2004; Wohlfahrt et al., 2005). In contrast, Hutyra et al. (2008) found good agreement between mean annual ecosystem respiration of a tropical forest, derived by light curves and from nocturnal $u_{*}$ filtered EC data.

Based on the first law of thermodynamics, in an ideal closed system outgoing energy is expected to balance 
incoming energy, resulting in a hypothetical 1:1 regression line. The regression slope of $0.79 \pm 0.0063$ and intercept of $22.9 \pm 1.96$ and EBR ratio of 0.86 for the period from May to August for the Lägeren site corresponds very well to the mean energy balance published for 22 FLUXNET sites (mean budget closure of 0.79 , intercept range of -32.9 to 36.9, mean EBR=0.84, (Wilson et al., 2002). For forest sites, mean budget closure values of average 0.80 to 0.87 were reported (Aubinet et al., 2000; Barr et al., 2006). These sites however, are located in far less complex topography, typically on flat ground. Based on the premise that the energy budget closure is a reliable quality measure of EC flux measurements, our measurements carried out over complex terrain should then be of the same overall quality as those over flat terrain (cf. Hiller et al., 2008).

As advection is accounting for $36 \%$ of the $\mathrm{C}$ budget at our site and is a major factor for the underestimation of the turbulent fluxes, we hypothesized that exclusion of periods with strong advection should improve the energy budget closure (cf. Barr et al., 2006; Oncley et al., 2007). Our data, however, do not support this idea and indicate rather that the energy budget closure is not suitable to detect the occurrence of advection, as was also found within the ADVEX campaign (Feigenwinter et al., 2008; Moderow et al., 2009). One explanation might be that EC fluxes of water and sensible heat are more robust than $\mathrm{CO}_{2}$ fluxes as stated by Lee and $\mathrm{Hu}$ (2002). A reason for the poor improvement of the energy budget closure could be that the slope of the regression line is primarily determined by the range of the incoming short-wave radiation, e.g., by day-time values. But as advection is most prominent during night at our study site, advection might affect the energy budget closure calculation only slightly. The energy budget closure gap can apparently not be explained by the occurrence of advection, at least not at our site. In summary, if the energy budget closure is considered a sound indicator for the quality of EC flux measurements, then our data presented here provide strong evidence that EC flux measurements carried out on a relatively steep but spatially homogeneous mountain slope are of comparable quality as sites with flat ground.

\section{Conclusions}

With a relatively simple measurement set-up, we got realistic and explainable estimates of horizontal advection for our research site. By physical correction of our EC data for horizontal advection we got reasonable estimates of fluxes on a daily, monthly and seasonal basis, that were in good agreement with data that were filtered by a $\mathrm{u}_{*}$ threshold of $0.3 \mathrm{~m} \mathrm{~s}^{-1}$. A cross validation with (a) chamber measurements of soil respiration, (b) respiration fluxes derived from light response curves, and (c) the energy budget closure indicated that EC fluxes corrected for advection as we propose here are consistent with other flux estimates. However, this simplification can only be considered valid at sites with strongly channeled wind flow and thus a 2-D character of the flux footprint.

Although steep sloping sites are commonly challenged as not suitable for EC measurements due to a large advection component, we could show that advection at the Lägeren site with a slope angle of $24^{\circ}$ is well in the range with advection measurements on less steep slopes or even over flat terrain. Based on the energy budget closure criterion it can even be deduced that such mountain slope sites are as suitable for EC measurements as most other existing flux sites.

Acknowledgements. Meteorological data were made available through MeteoSwiss, Federal Office of Meteorology and Climatology, Switzerland, precipitation data by the Swiss air quality monitoring network (NABEL). We thank our technician Peter Plüss (ETH Zurich) for his support in preparation, installation and maintenance of all measurement equipment. Special thanks go to Philip Vock, the forester of the Lägeren, who tolerates and supports all of our measurements in his forest. We thank the reviewers for their valuable comments and advices and Christian Feigenwinter (University of Basel) for constructive discussions. The research project was funded by the ETH Zurich, Switzerland (ETH research grant TH-10 06-2).

Edited by: G. Wohlfahrt

\section{References}

Acevedo, O. C., Moraes, O. L. L., Degrazia, G. A., Fitzjarrald, D., Manzi, A. O., and Campos, J. G.: Is friction velocity the most appropriate scale for correction of nocturnal carbon dioxide fluxes? Agr. Forest Meteorol., 149, 1-10, 2009.

Aubinet, M., Grelle, A., Ibrom, A., Rannik, U., Moncrieff, J., Foken, T., Kowalski, A., Martin, P. H., Berbigier, P., Bernhofer, C., Clement, R., Elbers, J., Granier, A., Gruenwald, T., Morgenstern, K., Pilegaard, K., Rebmann, C., Snijders, W., Valentini, R., and Vesala, T.: Estimates of annual net carbon and water exchange of forests: The euroflux methodology, in: Advances in ecological research, edited by: Fitter, A. H., and Raffaelli, D., Academic Press, 113-175, 2000.

Aubinet, M., Heinesch, B., and Yernaux, M.: Horizontal and vertical $\mathrm{CO}_{2}$ advection in a sloping forest Bound.-Lay. Meteorol., 108, 397-417, 2003.

Aubinet, M., Berbigier, P., Bernhofer, C., Cescatti, A., Feigenwinter, C., Granier, A., Gruenwald, T., Havrankova, K., Heinesch, B., Longdoz, B., Marcolla, B., Montagnani, L., and Sedlak, P.: Comparing $\mathrm{CO}_{2}$ storage and advection conditions at night at different carboeuroflux sites, Bound.-Lay. Meteorol., 116, 63-94, 2005.

Aubinet, M.: Eddy covariance $\mathrm{CO}_{2}$ flux measurements in nocturnal conditions: An analysis of the problem, Ecol. Appl., 18, 13681378, 2008.

Aubinet, M., Feigenwinter, C., Bernhofer, C., Canepa, E., Lindroth, A., Montagnani, L., Rebmann, C., Sedlak, P., and Van Gorsel, E.: Direct advection measurements do not help to solve the nighttime 
$\mathrm{CO}_{2}$ closure problem - evidence from three different forests, Agr. Forest Meteorol., 150, 655-664, 2010.

Baldocchi, D., Finnigan, J., Wilson, K., Paw U, K. T., and Falge, E.: On measuring net ecosystem carbon exchange over tall vegetation on complex terrain, Bound.-Lay. Meteorol., 96, 257-291, 2000.

Baldocchi, D.: Assessing the eddy covariance technique for evaluating carbon dioxide exchange rates of ecosystems: Past, present and future, Global Change Biol., 9, 479-492, 2003.

Barr, A. G., Morgenstern, K., Black, T. A., McCaughey, J. H., and Nesic, Z.: Surface energy balance closure by the eddycovariance method above three boreal forest stands and implications for the measurement of the $\mathrm{CO}_{2}$ flux, Agr. Forest Meteorol., 140, 322-337, 2006.

Carrara, A., Kowalski, A., Neirynck, J., Janssens, I. A., Curiel Yuste, J., and Ceulemans, R.: Net ecosystem exchange of a mixed forest in Belgium over 5 years, Agr. Forest Meteorol., 119, 209-227, 2003.

Curiel Yuste, J., Nagy, M., Janssens, I. A., Carrara, A., and Ceulemans, R.: Soil respiration in a mixed temperate forest and its contribution to total ecosystem respiration, Tree Physiology, 25, 609-619, 2005.

Davidson, E. A., Richardson, A. D., Savage, K. E., and Hollinger, D. Y.: A distinct seasonal pattern of the ratio of soil respiration to total ecosystem respiration in a spruce-dominated forest, Global Change Biol., 12, 230-239, 2006.

Defant, F.: A theory of slope winds, along with remarks on the theory of mountain winds and valley winds, in: Alpine meteorology edited by: Whiteman, C. D., and Dreiseitl, E., F. PNL-5141/ASCOT-84-3, Pacific Northwest Laboratory, Richland, Washington, 121, 1949.

Eugster, W., McFadden, J. J., and Chapin, F. S.: A comparative approach to regional variation in surface fluxes using mobile eddy correlation towers, Bound.-Lay. Meteorol., 85, 293-307, 1997.

Eugster, W., Kling, G., Jonas, T., McFadden, J. J., Wuest, A., MacIntyre, S., and Chapin, F. S.: $\mathrm{CO}_{2}$ exchange between air and water in an arctic alaskan and midlatitude swiss lake: Importance of convective mixing, J. Geophys. Res., 108, 4362, 19 pp., doi:10.1029/2002JD002653, 2003.

Eugster, W., Zeyer, K., Zeeman, M., Michna, P., Zingg, A., Buchmann, N., and Emmenegger, L.: Methodical study of nitrous oxide eddy covariance measurements using quantum cascade laser spectrometery over a Swiss forest, Biogeosciences, 4, 927-939, doi:10.5194/bg-4-927-2007, 2007.

Falge, E., Baldocchi, D., Olson, R., Anthoni, P., Aubinet, M., Bernhofer, C., Burba, G. G., Ceulemans, R., Clement, R., Dolman, H., Granier, A., Gross, P., Gruenwald, T., Hollinger, D., Jensen, N. O., Katul, G., Keronen, P., Kowalski, A., Lai, C. T., Law, B., Meyers, T., Moncrieff, J., Moors, E., Munger, J. W., Pilegaard, K., Rannik, U., Rebmann, C., Suyker, A., Tenhunen, J., Tu, K., Verma, S., Vesala, T., Wilson, K., and Wofsy, S.: Gap filling strategies for defensible annual sums of net ecosystem exchange, Agr. Forest Meteorol., 107, 43-69, 2001.

Falge, E., Baldocchi, D., Tenhunen, J., Aubinet, M., Bakwin, P., Berbigier, P., Bernhofer, C., Burba, G. G., Clement, R., Davis, K. J., Elbers, J. A., Goldstein, A. H., Grelle, A., Granier, A., Gudmundsson, J., Hollinger, D., Kowalski, A., Katul, G., Law, B. E., Malhi, Y., Meyers, T., Monson, R. K., Munger, J. W., Oechel, W., Paw U, K. T., Pilegaard, K., Rannik, U., Rebmann,
C., Suyker, A., Valentini, R., Wilson, K., and Wofsy, S.: Seasonality of ecosystem respiration and gross primary production as derived from fluxnet measurements, Agr. Forest Meteorol., 113, 53-74, 2002.

FAO (Food and Agriculture Organization of the United Nations): http://www.fao.org; http://www.mountainpartnership.org, last access: 12 August 2010, 2008.

Feigenwinter, C., Bernhofer, C., and Vogt, R.: The influence of advection on the short term $\mathrm{CO}_{2}$ budget in and above a forest canopy, Bound.-Lay. Meteorol., 113, 201-224, 2004.

Feigenwinter, C., Bernhofer, C., Eichelmann, U., Heinesch, B., Hertel, M., Janous, D., Kolle, O., Lagergren, F., Lindroth, A., Minerbi, S., Moderow, U., Moelder, M., Montagnani, L., Queck, R., Rebmann, C., Vestin, P., Yernaux, M., Zeri, M., Ziegler, W., and Aubinet, M.: Comparison of horizontal and vertical advective $\mathrm{CO}_{2}$ fluxes at three forest sites, Agr. Forest Meteorol., 148, 12-24, 2008.

Finnigan, J. J., Clement, R., Malhi, Y., Leuning, R., and Cleugh, H. A.: A re-evaluation of long-term flux measurement techniques. Part i: Averaging and coordinate rotation Bound.-Lay. Meteorol., 107, 1-48, 2003.

Foken, T. and Wichura, B.: Tools for quality assessment of surfacebased flux measurements, Agr. Forest Meteorol., 78, 83-105, 1996.

Göckede, M., Foken, T., Aubinet, M., Aurela, M., Banza, J., Bernhofer, C., Bonnefond, J. M., Brunet, Y., Carrara, A., Clement, R., Dellwik, E., Elbers, J., Eugster, W., Fuhrer, J., Granier, A., Grünwald, T., Heinesch, B., Janssens, I. A., Knohl, A., Koeble, R., Laurila, T., Longdoz, B., Manca, G., Marek, M., Markkanen, T., Mateus, J., Matteucci, G., Mauder, M., Migliavacca, M., Minerbi, S., Moncrieff, J., Montagnani, L., Moors, E., Ourcival, J.-M., Papale, D., Pereira, J., Pilegaard, K., Pita, G., Rambal, S., Rebmann, C., Rodrigues, A., Rotenberg, E., Sanz, M. J., Sedlak, P., Seufert, G., Siebicke, L., Soussana, J. F., Valentini, R., Vesala, T., Verbeeck, H., and Yakir, D.: Quality control of CarboEurope flux data - Part 1: Coupling footprint analyses with flux data quality assessment to evaluate sites in forest ecosystems, Biogeosciences, 5, 433-450, doi:10.5194/bg-5-433-2008, 2008.

Goulden, M. L., Munger, J. W., Fan, S. M., Daube, B. C., and Wofsy, S.: Measurements of carbon sequestration by long-term eddy covariance: Methods and a critical evaluation of accuracy, Global Change Biol., 2, 169-182, 1996.

Gu, L., Falge, E. M., Boden, T., Baldocchi, D. D., Black, T. A., Saleska, S. R., Suni, T., Verma, S. B., Vesala, T., Wofsy, S., and Xu, L.: Objective threshold determination for nighttime eddy flux filtering, Agr. Forest Meteorol., 128, 179-197, 2005.

Heinesch, B., Yernaux, M., and Aubinet, M.: Some methodological questions concerning advection measurements: A case study, Bound.-Lay. Meteorol., 122, 457-478, 2007.

Hiller, R., Zeeman, M. J., and Eugster, W.: Eddy-covariance flux measurements in the complex terrain of an alpine valley in Switzerland, Bound.-Lay. Meteorol., 127, 449-467, 2008.

Huber, U. M., Bugmann, H., and Reasoner, M.: Global change and mountain regions: An overview of current knowledge, Advances in global change research edited by: Huber, U. M., Bugmann, H., and Reasoner, M., Springer Berlin, 2005.

Hui, D., Wan, S., Su, B., Katul, G., Monson, R., and Luo, Y.: Gapfilling missing data in eddy covariance measurements using mul- 
tiple imputation (mi) for annual estimations, Agr. Forest Meteorol., 121, 93-111, 2004.

Hutyra, L. R., Munger, J. W., E, H.-P., Saleska, S. R., RestrepoCoupe, N., Daube, B. C., de Camargo, P. B., and Wofsy, S.: Resolving systematic errors in estimates of net ecosystem exchange of $\mathrm{CO}_{2}$ and ecosystem respiration in a tropical forest biome, Agr. Forest Meteorol., 148, 1266-1279, 2008.

Janssens, I. A., Freibauer, A., Ciais, P., Smith, P., Nabuurs, G. J., Folberth, G., Schlamadinger, B., Hutjes, R. W. A., Ceulemans, R., Schulze, E. D., Valentini, R., and dolman, A. J.: Europe's terrestrial biosphere absorbs 7 to $12 \%$ of european anthropogenic $\mathrm{CO}_{2}$ emissions, Science, 300, 1538-1542, 2003.

Kutsch, W. L., Kolle, O., Rebmann, C., Knohl, A., Ziegler, W., and Schulze, E. D.: Advection and resulting $\mathrm{CO}_{2}$ exchange uncertainty in a tall forest in Central Germany, Ecol. Appl., 18, 13911405, 2009.

Lee, X.: On micrometeorological observations of surface-air exchange over tall vegetation Agr. Forest Meteorol., 91, 39-49, 1998.

Lee, X. and Hu, X.: Forest-air fluxes of carbon, water and energy over non-flat terrain, Bound.-Lay. Meteorol., 103, 277-301, 2002.

Leuning, R., Zegelin, S. J., Jones, K., Keith, H., and Hughes, D.: Measurement of horizontal and vertical advection of $\mathrm{CO}_{2}$ within a forest canopy, Agr. Forest Meteorol., 148, 1777-1797, 2008.

Luyssaert, S., Schulze, E. D., Börner, A., Knohl, A., Hessenmöller, D., Law, B. E., Ciais, P., and Grace, J.: Old-growth forests as a global carbon sink, Nature 455, 213-215, 2008.

Marcolla, B., Cescatti, A., Montagnani, L., Manca, G., Kerschbaumer, G., and Minerbi, S.: Importance of advection in the atmospheric $\mathrm{CO}_{2}$ exchanges of an alpine forest, Agr. Forest Meteorol., 130, 193-206, 2005.

Mauder, M., Foken, T., Clement, R., Elbers, J. A., Eugster, W., Grnwald, T., Heusinkveld, B., and Kolle, O.: Quality control of CarboEurope flux data - Part II: Inter-comparison of eddycovariance software, Biogeosciences Discuss., 4, 4067-4099, doi:10.5194/bgd-4-4067-2007, 2007.

MeteoSwiss. Federal office of meteorology and climatology: http://www.meteoswiss.admin.ch/web/en/weather.html; http://www.meteoswiss.admin.ch/web/en/climate/observation systems/surface.html, 2010.

Metzger, M. J., Bunce, R. G. H., Leemans, R., and Viner, D.: Projected environmental shifts under climate change: European trends and regional impacts, Environ. Conserv., 35, 64-75, 2008.

Moderow, U., Aubinet, M., Feigenwinter, C., Kolle, O., Lindroth, A., Moelder, M., Montagnani, L., Rebmann, C., and Bernhofer, C.: Available energy and energy balance closure at four coniferous forest sites across europe, Theor. Appl. Climatol., 98, 397412, 2009.

Moffat, A. M., Papale, D., Reichstein, M., Hollinger, D. Y., Richardson, A. D., Barr, A. G., Beckstein, C., Braswell, B. H., Churkina, G., Desai, A. R., Falge, E., Gove, J. H., Heimann, M., Hui, D., Jarvis, A. J., Kattge, J., Noormets, A., and Stauch, V. J.: Comprehensive comparison of gap-filling techniques for eddy covariance net carbon fluxes, Agr. Forest Meteorol., 147, 209-232, 2007.

Moffat, A. M.: A new methodology to interpret high resolution measurements of net carbon fluxes between the terrestrial ecosystems and the atmosphere., PhD, Friedrich Schiller Univer- sity, Jena, 2010.

Montheith, J. L. and Unsworth, M. H.: Principles of environmental physics, Edward Arnold, London, 1990.

Moureaux, C., Debacq, A., Bodson, B., Heinesch, B., and Aubinet, M.: Annual net ecosystem carbon exchange by a sugar beet crop, Agr. Forest Meteorol., 139, 25-39, 2006.

NABEL. Swiss air quality monitoring network: http://www.bafu. admin.ch/luft/00612/00625/index.html, 2010.

Oncley, S. P., Foken, T., Vogt, R., Kohsiek, W., DeBruin, H. A. R., Bernhofer, C., Christen, A., van Gorsel, E., Grantz, D., Feigenwinter, C., Lehner, I., Liebethal, C., Liu, H., Mauder, M., Pitacco, A., Ribeiro, L., and Weidinger, T.: The energy balance experiment Ebex-2000. Part i: Overview and energy balance, Bound.-Lay. Meteorol., 123, 1-28, 2007.

Papale, D., Reichstein, M., Aubinet, M., Canfora, E., Bernhofer, C., Kutsch, W., Longdoz, B., Rambal, S., Valentini, R., Vesala, T., and Yakir, D.: Towards a standardized processing of Net Ecosystem Exchange measured with eddy covariance technique: algorithms and uncertainty estimation, Biogeosciences, 3, 571-583, doi:10.5194/bg-3-571-2006, 2006.

R Development Core Team: R: A language and environment for statistical computing, in, $\mathrm{R}$ foundation for statistical computing, Vienna, Austria, 2006.

Reichstein, M., Tenhunen, J. D., Roupsard, O., Ourcival, J. M., Miglietta, F., Peressotti, A., Pecchiari, M., Tirone, G., and Valentini, R.: Severe drought effects on ecosystem $\mathrm{CO}_{2}$ and $\mathrm{H}_{2} \mathrm{O}$ fluxes at three mediterranean evergreen sites: Revision of current hypotheses?, Global Change Biol., 8, 999-1017, 2002.

Reichstein, M., Falge, E., Baldocchi, D., Papale, D., Aubinet, M., Berbigier, P., Bernhofer, C., Buchmann, N., Gilmanov, T., Granier, A., Gruenwald, T., Havrankova, K., Ilvesniemi, H., Janous, D., Knohl, A., Laurila, T., Lohila, A., Loustau, D., Matteucci, G., Meyers, T., Miglietta, F., Ourcival, J. M., Pumpanen, J., Rambal, S., Rotenberg, E., Sanz, M., Tenhunen, J., Seufert, G., Vaccari, F., Vesala, T., Yakir, D., and Valentini, R.: On the separation of net ecosystem exchange into assimilation and ecosystem respiration: Review and improved algorithm, Global Change Biol., 11, 1424-1439, 2005.

Rühr, N. K., Knohl, A., and Buchmann, N.: Environmental variables controlling soil respiration on diurnal, seasonal and annual time-scales in a mixed mountain forest in switzerland, Biogechemistry, doi:10.1007/s10533-10009-19383-z, 2009.

Ruppert, J., Mauder, M., Thomas, C., and Luers, A.: Innovative gap-filling strategy for annual sums of $\mathrm{CO}_{2}$ net ecosystem exchange, Agr. Forest Meteorol., 138, 5-18, 2006.

Schimel, D., Kittel, T. G. F., Running, S., Monson, R., Turnipseed, A. A., and Anderson, D.: Carbon sequestration studied in western U.S. Mountains, EOS Trans. AGU, 83, 445-449, 2002.

Staebler, R. M. and Fitzjarrald, D. R.: Observing subcanopy $\mathrm{CO}_{2}$ advection, Agr. Forest Meteorol., 122, 139-156, 2004.

Van Gorsel, E., Leuning, R., Cleugh, H. A., Keith, H., and Suni, T.: Nocturnal carbon efflux: Reconciliation of eddy covariance and chamber measurements using an alternative to the $\mathrm{u}^{*}$-threshld filtering technique, Tellus, 59, 397-403, 2007.

Van Gorsel, E., Leuning, R., Cleugh, H. A., Keith, H., Kirschbaum, M. U. F., and Suni, T.: Application of an alternative method to derive reliable estimates of nightime respiration from eddy covariance measurements in moderately complex terrain, Agr. Forest Meteorol., 148, 1174-1180, 2008. 
Wagner, A.: Theory and observation of periodic mountain winds, in: Alpine meteorology edited by: Whiteman, C. D. and Dreiseitl, E., 1938.

Whiteman, C. D., and Doran, J. C.: The relationship between overlying synoptic-scale flows and winds within a valley, Journal of Applied Meteorology 32, 1669-1682, 1993.

Whiteman, C. D.: Mountain meteorology: Fundamentals and applications, Oxford University Press, New York, Oxford, 1-355 pp., 2000.

Wilson, K., Goldstein, A., Falge, E., Aubinet, M., Baldocchi, D., Berbigier, P., Bernhofer, C., Ceulemans, R., Dolman, H., Field, C., Grelle, A., Ibrom, A., Law, B. E., Kowalski, A., Meyers, T., Moncrieff, J., Monson, R., Oechel, W., Tenhunen, J., Valentini, R., and Verma, S.: Energy balance closure at fluxnet sites, Agr. Forest Meteorol., 113, 223-243, 2002.
Wohlfahrt, G., Anfang, C., Bahn, M., Haslwanter, A., Newesely, C., Schmitt, M., Droesler, M., Pfadenhauer, J., and Cernusca, A.: Quantifying nighttime ecosystem respiration of a meadow using eddy covariance, chambers and modelling, Agr. Forest Meteorol., 128, 141-162, 2005.

World Conservation Monitoring Centre (WCMC) of the UNEP: http://www.unep-wcmc.org, last access: 12 August 2010, 2008.

$\mathrm{Xu}, \mathrm{L}$. and Baldocchi, D.: Seasonal variation in carbon dioxide exchange over a mediterranean annual grassland in california, Agr. Forest Meteorol., 1232, 79-96, 2004.

Yi, C., Anderson, D. E., Turnipseed, A. A., Burns, S. P., Sparks, J. P., Stannard, D. I., and Monson, R. K.: The contribution of advective fluxes to net ecosystem exchange in a high-elevation, subalpine forest, Ecol. Appl., 18, 1379-1390, 2008. 